\title{
The online forum as a place of exchange of professional experience for Russian and Polish teachers
}

\author{
Elena Asmakovets ${ }^{1 *}$ and Stawomir Koziej ${ }^{1,2}$ \\ ${ }^{1}$ Dostoevsky Omsk State University, Department of Social Work, Pedagogy and Psychology, Omsk, \\ Russia \\ ${ }^{2}$ Jan Kochanowski University in Kielce, Faculty of Education and Psychology, Kielce, Poland
}

\begin{abstract}
In the modern world, many aspects of social and professional life are transferred to the Internet. This also concerns the everyday functioning of teachers, particularly during the COVID-19 pandemic. The study conducted sought to determine what professional problems involve teachers who seek solutions in the virtual space. The aim of the study was to explore, describe and elucidate the matter examined. In order to explicate the current state of affairs, the following research problem was formulated: what professional issues are discussed by Russian and Polish teachers on online forums? The method for finding the answer to this question was an analysis of the content published on online teacher forums. As revealed by the analysis, the participants of online discussions raise various topics, related to the economic aspect and the prestige of the teacher profession, and everyday functioning at school as an educational and formational environment. The scope of subjects discussed proves to be fairly broad. The research showed the principal interests of Russian and Polish teachers with regard to the topics raised, and confirmed that online forums are an appropriate place to hold discussions, especially in the times of limited direct contact. Participating in online discussions allows teachers to search for answers to questions related to their profession, express their opinions on professional matters, and obtain legal advice or advice on the management of the education process.
\end{abstract}

Keywords: Internet, social networks, online forums, teachers.

\section{Introduction}

Nowadays, information technology accompanies us in almost all areas of life. Efficient use of its products and tools constitutes one of the conditions of successful social functioning. Modern man lives in a dynamically changing world replete in the tools of information technology, and social media activity is a common part of their existence. The Internet has become a space not only for maintaining friendships but also for engaging in new, more casual social interactions. Using social media allows for communicating with friends, sharing information about everyday life, building one's online image, and following news

${ }^{*}$ Corresponding author: asmakovec alena@mail.ru 
about other people's lives. This is also the case for everyday functioning of teachers, who search for information related to their professional lives via the Internet. Due to the circumstances of global coronavirus pandemic, switching schools to remote learning, and the resulting physical isolation, social contacts of this professional group have moved to a great extent to the virtual space [1].

\section{Literature review}

Information technologies permeate every aspect of modern life. The availability of media and their broad application are meaningful for the history of human development. Contemporary teachers to a great extent belong to the cybergeneration, and thus are people who successfully function in the virtual space [2, 3].

Humans are social beings, and some form of identification with other people is always at the core of human interactions [4]. Contacts and relationships are fundamental conditions for human existence and development, as they fulfil the need for belonging located in the middle of Maslow's hierarchy of needs. According to his theory [5], proper functioning of the individual is achieved by fulfilling the following needs: physiological, safety, love and belonging, esteem and self-actualisation. In the days of disrupted social functioning, caused by limited physical contact, the virtual space has, to a greater degree than before, become a place where social needs - such as the need for belonging, communication, organisation, emotional bond, conformity, socialisation, social utility, gratification, acceptance, participation, safety and autonomy [6] - may be relatively successfully fulfilled.

Teachers, who largely represent the digital society and who are equipped with media competencies that allow them to efficiently navigate the virtual reality [7], often operate online, as the Internet gives them the opportunity to fulfil their needs [8, 9].

The virtual space gives rise to online communities that are defined by their members' shared interests. These communities give support [10], a sense of belonging, social identity, and an opportunity to achieve common goals; they foster informal education through collective learning and exchange of information $[11,12]$, and enable contact with other people.

Online forums are a place where those interested can search for information on the ways of solving problems, ask questions and obtain advice. They can also give their opinions about particular solutions [13, 14].

Making active use of the opportunities offered by online forums mostly depends on an individual's personality [15]. Not everyone has the need to participate in such discussions.

\section{Methods}

The subject of the study were the issues related to everyday professional life, raised by teachers in the virtual space. The aim was to explore, describe and elucidate the matter examined, that is, to identify principal problems discussed by teachers on online forums. In order to explicate the current state of affairs, the following research problem was formulated: what professional issues are discussed by Russian and Polish teachers on online forums? The contents were analysed by means of qualitative research [16, 17]. A matrix of categories was used for the purpose of analysis. The matrix consisted of a collection of posts written by forum users, grouped into categories according to the problems raised by the teachers.

The study analysed entries of the users of two selected online teacher forums. The first one was "Teachers' Portal" (https://www.uchportal.ru/forum/), addressed to Russian teachers, whereas the second one was "45minut.pl Forum for Teachers" 
(https://www.45minut.pl/forum/), addressed to Polish teachers. Both forums are features on websites that also offers other contents such as: publications, databases of tests, didactic materials and legal acts regulating education law. The main similarity between the two forums is their high popularity in their respective countries and their availability to all teachers, the first being Russian nationwide, and the second one being Polish nationwide. The fundamental difference between these communities lies in the Polish teachers' significantly greater willingness to creating new threads and publishing posts despite a comparable number of registered users on both forums. As of October 7, 2020, the number of members of "Teachers' Portal" amounted to 131,743 users who created 1,073 threads and published 35,879 posts. At the same time, the statistics for "45minut.pl Forum for Teachers" were as follows: 158,665 users, 9,036 threads and 125,609 posts.

\section{Results}

Both the Russian and the Polish forum allows the users to publish posts in threads that can be created within particular sections as imposed by the administrator. The analysis excluded posts published in sections dedicated to the methodology of teaching different subjects on different levels of education. While these issues relate to the teachers' professional lives, they are scattered in numerous threads with relatively few entries, and they focus on very specific problems that concern only a narrow group of professionals. The analysis did not include threads intended for exchanging greetings, jokes and small talk. Although very popular on both portals, these threads do not touch upon purely professional matters. The study focused on posts published in threads that concerned larger groups of users.

The analysis began with the selection of threads characterised by the largest number of entries. However, the number of users participating in a given thread is not the only measure of the thread's popularity. Another criterion for determining the level of interest in a given problem is the number of views, as it sometimes happens that a thread with only a few entries is watched by many users. The most popular threads on the Russian and the Polish forum, along with the number of posts and views, are presented in Tables 1 and 2.

Table 1. The most popular threads on the Russian "Teachers' Portal".

\begin{tabular}{|c|c|c|}
\hline Thread title & $\begin{array}{c}\text { Number of } \\
\text { posts }\end{array}$ & $\begin{array}{c}\text { Number of } \\
\text { views }\end{array}$ \\
\hline USE [Unified State Exam] - all pros and cons & 1,097 & 213,631 \\
\hline Average teacher salaries by region! & 979 & 323,455 \\
\hline Electronic magazines and grade books & 485 & 117,091 \\
\hline "Let them talk" podcast! Why humiliate teachers? & 472 & 108,100 \\
\hline Remuneration for work on the USE & 349 & 149,311 \\
\hline Pedagogical situations at school and outside school & 328 & 73,918 \\
\hline How are you doing at work right now? & 307 & 60,642 \\
\hline Point counting system. Is it fair? & 276 & 78,812 \\
\hline Additional vocational training for teachers. Necessary? & 239 & 69,805 \\
\hline Teacher and school administration staff salaries. Official data & 218 & 98,329 \\
\hline Class teacher's duties as divine punishment & 199 & 58,478 \\
\hline Online education software & 198 & 32,116 \\
\hline Reports (paperwork) & 197 & 46,693 \\
\hline Troublesome teenagers & 194 & 41,299 \\
\hline How to find advice on school administration & 186 & 84,982 \\
\hline "The School" TV series. Why broadcast such nonsense? & 181 & 40,827 \\
\hline Let's rate legal antivirus software for schools & 175 & 71,175 \\
\hline The state of school toilets & 169 & 28,558 \\
\hline Private lessons: allow or forbid? & 154 & 41,999 \\
\hline
\end{tabular}


The most popular thread on the Russian portal was "USE [Unified State Exam] - all pros and cons" (1,097 posts and 213,631 views). Implemented in 2009 after eight years of testing, the Unified State Exam - the nationwide high school graduation exam - continues to stir up emotions in the teaching community. However, the most interest was shown in threads concerning remuneration, as proved by the popularity of such threads as: "Average teacher salaries by region!" (979 posts, 323,455 views), "Remuneration for work on the USE" (349 posts, 149,311 views) and "Teacher and school administration staff salaries. Official data" (218 posts, 98,329 views). In total, these three threads (over 1,700 entries) were viewed over half a million times.

Table 2. The most popular threads on the Polish " 45 minut.pl Forum for Teachers".

\begin{tabular}{|c|c|c|}
\hline Thread title & $\begin{array}{c}\text { Number of } \\
\text { posts }\end{array}$ & $\begin{array}{c}\text { Number of } \\
\text { views }\end{array}$ \\
\hline $\begin{array}{c}\text { Nominated teacher exam - presentation } \\
\text { The "charter hour" - additional teaching hour resulting from } \\
\text { the Teacher's Charter }\end{array}$ & 1,715 & 634,440 \\
\hline Health leave & 8079 & 379,193 \\
\hline Nominated teacher exam 2014 - questions and answers & 796 & 382,861 \\
\hline Promotion to certified teacher & 794 & 435,021 \\
\hline Pregnancy rights & 747 & 245,234 \\
\hline The teacher's qualifications & 589 & 300,665 \\
\hline Discipline in the classroom & 536 & 268,513 \\
\hline Protest against sex education & 512 & 53,812 \\
\hline Pay rise. Advice? & 445 & 73,118 \\
\hline Termination of the employment contract & 409 & 112,857 \\
\hline Contract teacher exam & 379 & 428,776 \\
\hline The teacher's remuneration & 376 & 158,821 \\
\hline Teacher trainee... salary & 365 & 219,844 \\
\hline Employment contract & 354 & 63,281 \\
\hline Thirteenth salary & 336 & 135,147 \\
\hline The teacher's appearance & 330 & 124,065 \\
\hline Nominated teacher exam & 321 & 114,626 \\
\hline Loss of teaching hours & 306 & 49,053 \\
\hline
\end{tabular}

The most popular topic raised by Polish teachers was professional promotion. The thread "Nominated teacher exam - presentation" generated 1,715 entries that were viewed 634,440 times. Among 20 threads with the largest number of posts, 4 other threads touched upon the topic of professional promotion. In total, the 5 threads generated 4,005 posts and over 2 million views. Issues related to remuneration proved to be equally important for Polish teachers.

\section{Conclusion}

Internet forums prove to be an appropriate platform for education professionals to exchange thoughts. Teachers can make use of forums to hold group discussions, particularly in the days of enforced social isolation caused by the coronavirus pandemic and limited direct contact. Participating in online discussions allows teachers to search for answers to questions related to their profession, express their opinions on professional matters, and obtain legal advice or advice on the management of the education process. Both in Russia 
and Poland, it is the threads that touch upon remuneration that generate the most posts, although the scope of topics raised proves to be fairly broad.

\section{References}

1. B. Williamson, R. Eynon, J. Potter, Learning, Media and Technology, 45(2), 107-114 (2020). https://doi.org/10.1080/17439884.2020.1761641

2. D. Tapscott, Cyfrowa dorosłość. Jak pokolenie sieci zmienia nasz świat [Digital adulthood. How the network generation is changing our world] (Wydawnictwa Akademickie i Profesjonalne, Warszawa, 2010)

3. M. Prensky, On the Horizon, 9 (5), 1-6 (2001). https://doi.org/10.1108/10748120110424816

4. M. Marody, Jednostka po nowoczesności. Perspektywa socjologiczna [A unit after modernity. A sociological perspective] (Wydawnictwo Naukowe Scholar, Warszawa, 2014)

5. A. H. Maslow, Psychological Review, 50(4), 370-396 (1943)

6. T. Kocowski, Potrzeby człowieka: koncepcja systemowa [Human needs: systems concept] (Zakład Narodowy im. Ossolińskich, Wrocław, 1982)

7. S. Koziej, Contemporary University Education, 2, 62-65 (2017)

8. A. Rensfeldta, T. Hillmana, N. Selwynb, British Educational Research Journal, 44(2), 230-250 (April 2018). https://doi.org/10.1002/berj.3325

9. N. Selwyn, S. Nemorin, N. Johnson, Learning, Media and Technology, 42(4), 390-405 (2017). https://doi.org/10.1080/17439884.2016.1252770

10. N. Kelly, A. Antonio, Teaching and Teacher Education, 56, 138-149 (2016). https://doi.org/10.1016/j.tate.2016.02.007

11. M. Macia, I. Garcia, Teaching and Teacher Education, 55, 291-307 (2016). https://doi.org/10.1016/j.tate.2016.01.021

12. E. Tour, Technology, Pedagogy and Education, 26(2), 179-192 (2017). https://doi.org/10.1080/1475939X.2016.1196236

13. P. R. Morrow, Discourse Studies, 8(4), 531-548 (2006). https://doi.org/10.1177/1461445606061876

14. E. Asmakovets, S. Koziej Social, Educational and Art Problems, 35, 255-266 (2020)

15. S. J. Chen, E. J. Caropreso, Journal of Interactive Online Learning, 3(2) (2004)

16. A. Peräkylä, Analiza rozmów i tekstów [Analysis of conversations and texts], in Metody badań jakościowych, 2, 325-350 (Wydawnictwo Naukowe PWN, Warszawa, 2009)

17. B. De Wever, T. Schellens, M. Valcke, H. i Van Keer, Computers \& Education, 46(1), 6-28 (2006). https://doi.org/10.1016/j.compedu.2005.04.005 